\title{
Rupture voltage in mineral oil using the megger OTS 60pb equipment to determine its quality and use in transformers
}

\section{Tensión de ruptura en aceite mineral empleando el equipo megger OTS 60pb para determinar su calidad y utilizarse en transformadores}

\author{
ESCAMILLA-RODRÍGUEZ, Frumencio*†, LAGUNA-CAMACHO, Juan Rodrigo, RÍOS- \\ HERNÁNDEZ, Sara Anahí and JIMÉNEZ-CRISTÓBAL, Juan Daniel
}

Facultad de Ingeniería Mecánica y Eléctrica de la Universidad Veracruzana Región Poza Rica - Tuxpan

ID $1^{\text {st }}$ Autor: Frumencio, Escamilla-Rodriguez / ORC ID: 0000-0002-5075-1924, CVU CONACYT ID: 1134105

ID $1^{\text {st }}$ Coautor: Juan Rodrigo, Laguna-Camacho / ORC ID: 0000-0003-0974-5204

ID $2^{\text {nd }}$ Coautor: Sara Anahí, Rios-Hernandez / ORC ID: 0000-0002-2531-0342, CVU CONACYT ID: 1134110

ID $3^{\text {rd }}$ Coautor: Juan Daniel, Jiménez-Cristóbal / ORC ID: 0000-0002-9289-6806, CVU CONACYT ID: 1134107

DOI: $10.35429 / \mathrm{JOES} .2021 .24 .8 .25 .32$

Received 09 March, 2021; Accepted 28 June, 2021

\begin{abstract}
In this project some practices of mineral oil were made to determine the quality for its application in the electrical industry. Then the practices were developed in the laboratory of the Faculty of Mechanical and Electrical Engineering at Universidad Veracruzana using the Megger OTS 60 PB equipment, according to the current IEC 60156 and ASTM D1816 standards, new oil was used in a first analysis which proved to be of correct quality according to the standard, In the second case, oil polluted by the environment was used and it was of less quality since it did not pass the test according to the standard, and finally, degraded oil was used, which was less quality $\left(15^{\circ} \mathrm{C}\right)$ and heat was supplied up to $40^{\circ} \mathrm{C}$, taking readings at $40^{\circ} \mathrm{C}, 35^{\circ} \mathrm{C}, 30^{\circ} \mathrm{C}$ and $25^{\circ} \mathrm{C}$, giving favorable results due to the influence of the temperature on the mineral oil. In conclusion, according to the results of the test and the comparison with the parameters of the standards, the OTS60PB equipment operates correctly and the results of the equipment are reliable and it can be recommended that mineral oil can be used in transformers.
\end{abstract}

Quality, Mineral oil, Rupture Voltage

\section{Resumen}

En este trabajo se realizaron algunas prácticas de aceite mineral para determinar su calidad para su aplicación en la industria eléctrica. Las practicas se desarrollaron en el laboratorio de la Facultad de Ingeniería Mecánica y Eléctrica de la Universidad Veracruzana utilizando el Equipo Megger OTS 60 PB, de acuerdo a lo establecido con la normatividad vigente IEC 60156 y la ASTM D1816, se empleó aceite nuevo en un primer análisis que resulto ser de calidad correcta de acuerdo a la norma, en segundo caso se utilizó aceite contaminado por el medio ambiente y fue de mala calidad puesto que no paso la prueba de acuerdo a la norma y por último se utilizó aceite degradado el cual fue de mala calidad $\left(15^{\circ} \mathrm{C}\right)$ y se le suministro calor hasta los $40^{\circ} \mathrm{C}$, tomando lecturas en $40^{\circ} \mathrm{C}$, $35^{\circ} \mathrm{C}, 30^{\circ} \mathrm{C}$ y $25^{\circ} \mathrm{C}$, dando resultados favorables por la influencia de la temperatura en el aceite mineral. En conclusión, de acuerdo a los resultados de las prácticas y a la confrontación con los parámetros de las normas, el equipo OTS60PB opera correctamente y los resultados del equipo son confiables y se puede recomendar que el aceite mineral puede ser empleado en transformadores.

Calidad, Aceite mineral, Tensión de ruptura

Citation: ESCAMILLA-RODRÍGUEZ, Frumencio, LAGUNA-CAMACHO, Juan Rodrigo, RÍOS-HERNÁNDEZ, Sara Anahí and JIMÉNEZ-CRISTÓBAL, Juan Daniel. Rupture voltage in mineral oil using the megger OTS 60pb equipment to determine its quality and use in transformers. Journal of Experimental Systems. 2021. 8-24: 25-32

\footnotetext{
* Correspondence to Author (e-mail: fescamilla@uv.mx).

$\dagger$ Researcher contributing as first Author.
} 


\section{Introduction}

One of the problems faced by energy transformation equipment, as is the case of transformers used in CFE, is the cooling or insulation medium by means of gas or oil. In the case of oil, it is necessary to characterize it and verify its quality in order to use it in transformers, considering its physical and chemical properties and thus conclude whether it is possible to use this oil, as well as to use equipment to measure its dielectric strength. The oil is used as a cooling medium and when it comes into contact with solid elements such as the transformer core, it degrades and it is not possible to maintain the insulation oil in optimal conditions for the proper operation of power transformers.

This has led to the development of different physical, chemical and electrical tests that set the parameters of the oil characteristics and as a whole offer a diagnosis of the oil quality for the proper operation of the transformer. Taking into account this background, the research will allow verifying the quality of the oil with the parameters obtained when performing dielectric strength tests.

\section{Justification}

The insulating fluid that has the greatest use in electrical equipment is mineral oil, it fulfills the function of electrical insulation and cooling, this is due to its slow degradation period. It is important to know in time the quality of the fluid (mineral oil) to protect the electrical equipment in a power system.

The realization of this work is due to the scarce information on the dielectric strength test in the books that refer to the analysis of power systems. Most of them deal with electrical equipment testing in a general way and not with all the elements that make up an electrical equipment. This work will be of great support to the students of electrical engineering since the results of the practices of dielectric strength of mineral oil developed in the laboratory of FIME Poza Rica, Veracruz, are presented.

\section{Scope}

The evaluation of new mineral oil, in service and contaminated by the environment or degraded by means of the dielectric strength test with the Megger OTS60PB equipment of the FIME Poza Rica Laboratory of the Universidad Veracruzana is proposed, presenting the results of the tests developed as laboratory practices. Therefore, the design and construction of transformers is not considered, only the quality of the insulating fluid (oil) is evaluated, giving a recommendation according to the results.

\section{Considerations of IEC 60156 and ASTM D1816 standards for testing}

IEC 60156 recommends using a separate test cup for each type of insulating fluid to be tested. Fill them cover them then store them in a dry place. ASTM offers an alternative option of storing the empty beakers in a dust-free cabinet. Immediately prior to testing, those stored full should be emptied and then all surfaces, including the electrodes, should be rinsed with fluid taken from the same sample to be tested. The beaker should then be emptied again and carefully filled with the test sample, taking particular care to avoid the formation of bubbles. If the beaker was stored empty, or if it is to be used for a different fluid than that used for filling during storage, it should be cleaned with a suitable solvent prior to the rinsing and filling procedures described above.

ASTM D1816 specifies the use of a dry hydrocarbon solvent such as kerosene. Do not use solvents with a low boiling point, as they evaporate quickly, cooling the vessel and creating the risk of condensation. Commonly used solvents include acetone. Use clean, lintfree rags to clean the vessel. Avoid touching the electrodes inside during cleaning, and check that they are free of pits or scratches that can cause breakdown voltage values to be reduced.

\section{Methodology for the development of the mineral oil practices}

Pour the oil sample. The cleaning methods detailed in the national specifications for oil testing must be followed. Rinse the container with part of the oil sample. 
The sample should be poured into the container, avoiding the formation of air bubbles, up to the $500 \mathrm{ml}$ level mark. (Cover the test container when transferring the oil from the filling area to the oil test assembly to avoid contamination).

1. Clean the electrodes and all surrounding parts that come in contact with the oil sample to be tested.

It is recommended to flush with a portion of the oil sample prior to final filling with the oil to be tested. This may be convenient to allow the oil to stop dripping from the electrodes before removing the oil container after opening the door. This will reduce the need to clean the floor of the test chamber.

2. Set the spacing between the electrodes according to the requirement of the test specification undertaken.

The OTS $60 \mathrm{~PB}$ is a $0-60 \mathrm{kV}$ portable dielectric oil tester. Its size and weight make it suitable for on-site evaluation of insulating oil quality.

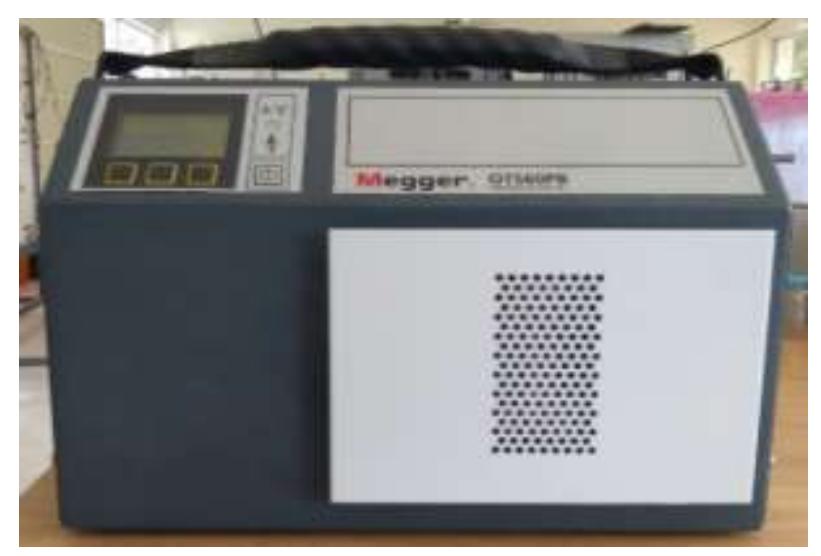

Figure 1 Schematic of an OTS60PB $70^{\circ} \mathrm{C}$ dielectric strength meter with a measurement range of $60 \mathrm{kV}$ and a scale division of $1 \mathrm{kV}$

The dielectric strength test is performed to determine the quality of the mineral oil and a chemical property $\mathrm{pH}$ or degree of acidity of the oil. In this study only the dielectric strength test will be carried out with the OTS 60PB equipment.

This equipment is user friendly and shows on screen the type of test to be selected according to the standard as shown in Table 1.

\begin{tabular}{|l|l|}
\hline VDE 0370 & AS 1767 \\
\hline BS 148 & ASTM D877 \\
\hline BS 5730 & ASTM D1816 \\
\hline BS 5730a LEPLC & CEI 10-1 \\
\hline BS 5874 & ГOCT 6581 \\
\hline IEC 60156 & IP 295 \\
\hline IEC 156 & NFC 27-221 \\
\hline WITHSTAND & SABS 555 \\
\hline 5-minute test & UNE 21 \\
\hline Self-check & \\
\hline
\end{tabular}

Table 1 Table of standards available for the equipment Source: Prepared by the team

3. Select the desired option and proceed as indicated in the following instructions on the screen fig. 2 .

\begin{tabular}{|c|c|}
\hline OPTIONS & \\
\hline BS 148: 1984 & \\
\hline BS 5730 a: 1979 & \\
\hline BA 5874: 1980 & \\
\hline IEC 156: 1973 & \\
\hline$\Delta \nabla$ & SELECT \\
\hline
\end{tabular}

Figure 2 Sample menu screen

\section{Dielectric strength of oil}

The dielectric strength of the oil is defined by the breakdown voltage or dielectric strength test. The exact method of performing the test is defined by the standard being used. The standard generally defines parameters such as the voltage value, the shape and size of the electrodes, the electrode spacing, the rate of rise of the test voltage, the number of times the test is repeated and whether the oil is agitated during the test.

\section{Standards for breakdown voltage values in insulating oil testing}

From the "Megger's Guide to Dielectric Breakdown Testing of Insulating Oils" we can take the following:

ASTM D877 standard the IEEE recommends it only for acceptance testing of new oil received from a supplier, either in bulk loads or containers, to ensure that the oil was properly stored and transported.

In these cases, a breakdown voltage value of $30 \mathrm{kV}$ or more is generally considered acceptable, while values below $25 \mathrm{kV}$ are considered unacceptable. Values between 25 and $30 \mathrm{kV}$ are considered questionable. For new oil, a minimum value of $30 \mathrm{kV}$. 
Use of disk-shaped electrodes with 25.4 $\mathrm{mm}$ ( 1 in.) diameter and at least $3.18 \mathrm{~mm}(0.125$ in.) thickness. These electrodes are made of polished bronze and are mounted so as to have their faces parallel and horizontally in line on the test vessel. It is specified that the edges should be sharp, with a radius of not more than 0.010 in $(0.254 \mathrm{~mm})$.

ASTM D1816 is more sensitive than D877 to moisture, aging and oxidation of the oil, and is more affected by the presence of particles in the oil.

Specifies the use of $36 \mathrm{~mm}$ diameter mushroom-shaped electrodes. The electrodes are made of bronze and must be polished and free of pickling, scratches, pitting or carbon build-up. The oil is agitated during the test sequence by a motor-driven two-vane impeller. The standard prescribes the impeller dimensions and pitch, as well as the operating speed, which must be between $200 \mathrm{rpm}$ and $300 \mathrm{rpm}$.

This method is very sensitive to dissolved gases. Excessive amounts of gas in the oil can lower the test results to the point that suitable oil samples with low moisture and particulate content will fail this test. It is important to keep this in mind when testing small insulated transformer oils in gas atmospheres and, in some cases, free-breathing transformers.

IEC 60156 is an international standard that appears in various forms, as IEC national member committees in several countries have adopted it.

\begin{tabular}{|c|c|}
\hline Standard test & $\begin{array}{l}\text { IEC156, EN60156, AS 1767, BS 5730, } \\
\text { IP 295, NFC 27, SABS } 555 \text { y UNE } 21\end{array}$ \\
\hline $\begin{array}{l}\text { Electrode } \\
\text { shape }\end{array}$ & \\
\hline $\begin{array}{l}\text { Electrode } \\
\text { spacing }\end{array}$ & $2.5 \mathrm{~mm}$ \\
\hline
\end{tabular}

Table 2 Comparative table of European standards

The IEC standard differs in several points from D1816, but the main difference is that the IEC standard allows the optional use of an impeller for agitation, the use of a magnetic ball stirrer or no agitation. The standard specifies that no statistically significant differences have been found between tests with or without shaking. The use of a magnetic stirrer is allowed only when there is no risk of removing magnetic particles from the oil sample under test.
When the oil is used as a coolant and therefore when circulating it, it will be agitated during the test. For example, oil from a transformer is normally circulated if it is used as a coolant, so an oil sample taken in this case will normally be agitated to ensure the best chance of detecting particulate contamination.

Circuit breaker oil is normally used statically so particles will naturally fall to the bottom where they are unlikely to cause problems. So in static applications an oil sample will not be agitated. The dielectric breakdown values of the IEC 60156 method are usually higher than those of the ASTM methods.

Possibly this is due in part to differences in ramp-up rate and electrode spacing when compared to D1816, and electrode shape when compared to D877. (The IEC electrode shape provides a more uniform electric field). The result is that for well-maintained transformers the breakdown voltages may be higher than the $60 \mathrm{kV}$ that the test instrument can reach. This may not be a problem when evaluating new oil from a supplier, or even oil in use, but often an actual breakdown voltage value is required. When testing with IEC 60156, therefore, it is advisable to use an instrument capable of applying a higher voltage. As with D1816, dissolved gas in the oil sample can reduce breakdown values, but the effect is much less pronounced than with IEC 60156.

Using the IEC 60156 test method $30 \mathrm{kV}$ or more. Oil that has been vacuum filtered in a laboratory must have a minimum dielectric breakdown voltage of $70 \mathrm{kV}$.

\section{Dielectric strength test of mineral oil}

A series of new oil practices were carried out to determine its quality under the following protocol:

a. Take oil temperature and ambient humidity.

b. Wash the cup with part of the sample. Fill the cup with another portion of the sample up to the $500 \mathrm{ml}$ mark. Place it in the test equipment.

c. Press the power button on the test equipment, let it stand for $2 \mathrm{~min}$.

d. Select the test standard on the screen, once selected press the start button. 
e. Take data of each rupture and at the end of the test take data of the mean and standard deviation if required by the standard.

f. Remove the cup from the equipment

g. Verify the results according to the standard.

h. Give diagnosis according to the standard

i. See sequence of standards

First practice with the UNE 21- 309- 89 standard

New mineral oil was considered as the first case. Two practices were carried out under the UNE 21 standard, where the humidity and temperature conditions are shown in tables, as well as the results of the breakdown voltage readings. The practice starts according to the protocol for the beginning of the test, the sequence is as follows.

\begin{tabular}{|c|c|c|c|c|c|}
\hline \multicolumn{2}{|c|}{ Temp } & \multicolumn{2}{|c|}{ Humidity } & \multicolumn{2}{|c|}{ Date } \\
\hline \multicolumn{2}{|c|}{$28^{\circ} \mathrm{C}$} & \multicolumn{2}{|c|}{$80 \%$} & \multicolumn{2}{|c|}{$16 / 10 / 2019$} \\
\hline & $\mathrm{kV}$ & LS & LI & Media & Ds \\
\hline 1 & 54 & \multirow{6}{*}{65} & \multirow{6}{*}{53} & \multirow{6}{*}{59} & \multirow{6}{*}{$2 \%$} \\
\hline 2 & 60 & & & & \\
\hline 3 & 60 & & & & \\
\hline 4 & 57 & & & & \\
\hline 5 & 58 & & & & \\
\hline 6 & 60 & & & & \\
\hline
\end{tabular}

Table 3 Results of practice No. 1 UNE 21 standard Source: Own Elaboration

\begin{tabular}{|c|c|c|c|c|c|}
\hline \multirow{2}{*}{\multicolumn{2}{|c|}{$\begin{array}{l}\text { Temp } \\
28^{\circ} \mathrm{C}\end{array}$}} & \multicolumn{2}{|c|}{ Humidity } & \multicolumn{2}{|c|}{ Date } \\
\hline & & \multicolumn{2}{|c|}{$80 \%$} & \multicolumn{2}{|c|}{$16 / 10 / 2019$} \\
\hline & $\mathrm{Kv}$ & Ls & $\mathrm{Li}$ & Media & Ds \\
\hline 1 & 58 & \multirow{6}{*}{633} & \multirow{6}{*}{51} & \multirow{6}{*}{577} & \multirow{6}{*}{$4 \%$} \\
\hline 2 & 54 & & & & \\
\hline 3 & 60 & & & & \\
\hline 4 & 56 & & & & \\
\hline 5 & 57 & & & & \\
\hline 6 & 59 & & & & \\
\hline
\end{tabular}

Table 4 Results of practice No. 2. UNE 21 Standard Source: Own Elaboration

Practices 3 and 4 were performed under BS 148, where humidity and temperature conditions are shown in tables, as well as the results of the breakdown voltage readings. A sample of the same transformer is used and the practice is carried out according to the test start protocol. This standard has a "pass/fail" option and displays the six results, the average and indicates whether the oil is of the correct quality.

\begin{tabular}{|c|c|c|}
\hline Temp & Humidity & Date \\
\hline $26^{\circ} \mathrm{C}$ & $67 \%$ & $18 / 10 / 2019$ \\
\hline & $\mathrm{kV}$ & Media \\
\hline 1 & 47 & \multirow{6}{*}{56} \\
\hline 2 & 60 & \\
\hline 3 & 60 & \\
\hline 4 & 51 & \\
\hline 5 & 60 & \\
\hline 6 & 55 & \\
\hline
\end{tabular}

Table 5 Results of practice No. 3. BS 148 Standard Source: Own Elaboration

\begin{tabular}{|l|l|l|}
\hline Temp & Humidity & \multicolumn{1}{c|}{ Date } \\
\hline $26{ }^{\circ} \mathrm{C}$ & $67 \%$ & $18 / 10 / 2019$ \\
\hline & $\mathrm{kV}$ & Media \\
\hline 1 & 47 & \multirow{2}{*}{53} \\
\hline 2 & 59 & \\
\hline 3 & 60 & \\
\hline 4 & 60 & \\
\hline 5 & 57 & \\
\hline 6 & 31 & \\
\hline
\end{tabular}

Table 6 Results of practice No. 4. BS 148 Standard Source: Own Elaboration

\section{Results}

The results obtained are compared below. First, the results of the practices are validated and then compared with the parameters established by the regulations in order to verify if the oil complies with the established stress ranges. Graphs 1 and 2 show the results of the UNE 21 test.

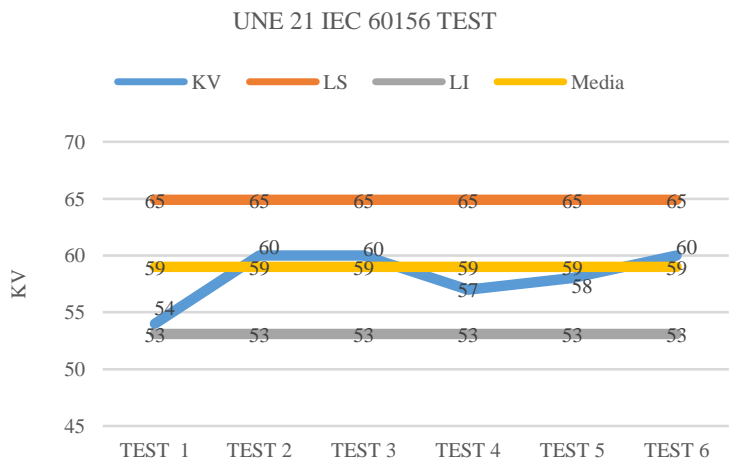

Graph 1 UNE 21 Practice 1. This test is within the parameters of the IEC 60156 standard, because the standard deviation does not exceed $4 \%$ of the upper and lower limits

Source: Own Elaboration 


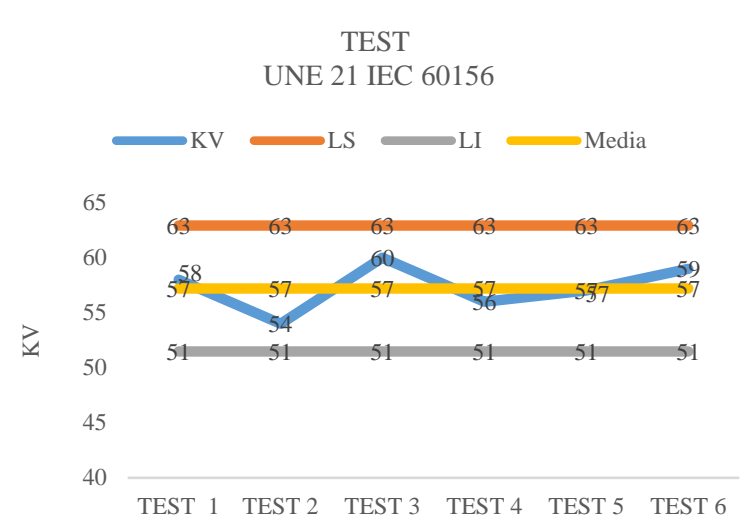

Graph 2 UNE 21 Práctica 2. Esta prueba está dentro de los parámetros de la norma IEC 60156, porque la desviación estándar no pasa del 3\% del límite superior e inferior

Source: Own Elaboration

Graphs 3 and 4 show the results of practices 3 and 4 BS 148

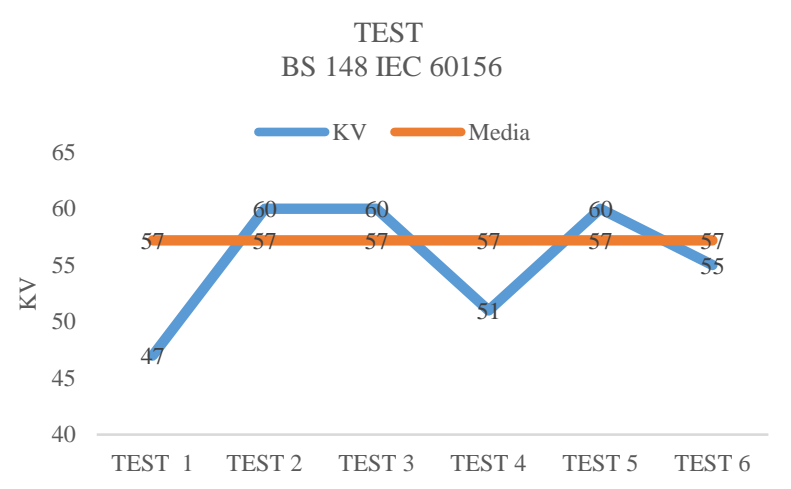

Graph 3 BS 148 Practice 3. Result of oil in service that also complies with the parameters of the standard Source: Own Elaboration

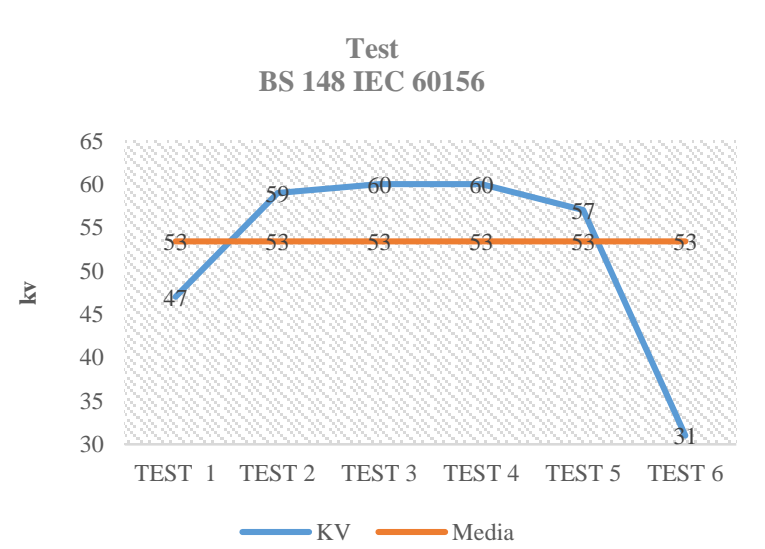

Graph 4 BS 148 practice 4. Result of oil in service that also complies with the parameters of the standard Source: Own Elaboration

In this second case, four tests were carried out and all were found to be of incorrect quality. This was under BS 148, where the humidity and temperature conditions are shown in tables, as well as the results of the breakdown voltage readings.
A few samples of contaminated oil are used and the practice is carried out according to the protocol. This standard has a "pass/fail" option and shows the 6 results, the mean and the result of the mineral oil condition.

\begin{tabular}{|l|l|}
\hline Temperature & $26^{\circ} \mathrm{C}$ \\
\hline Humidity & $66 \%$ \\
\hline Wind & $11 \mathrm{~km} / \mathrm{hr}$ \\
\hline Deviation & $\mathrm{S}=1.366$ \\
\cline { 2 - 2 } standard deviation & $S / \bar{x}=0.132$ \\
\hline \multicolumn{2}{|l|}{ Dielectric Capacity } \\
\hline 1 & $9 \mathrm{kV}$ \\
\hline 2 & $12 \mathrm{kV}$ \\
\hline 3 & $9 \mathrm{kV}$ \\
\hline 4 & $12 \mathrm{kV}$ \\
\hline 5 & $10 \mathrm{kV}$ \\
\hline 6 & $10 \mathrm{kV}$ \\
\hline Average voltage: $10 \mathrm{Kv}$ \\
\hline
\end{tabular}

Table 7 Results of practice No. 5. BS 148 Standard Source: Own Elaboration

The four practices were then analyzed as a whole using a comparative matrix and the results were plotted.

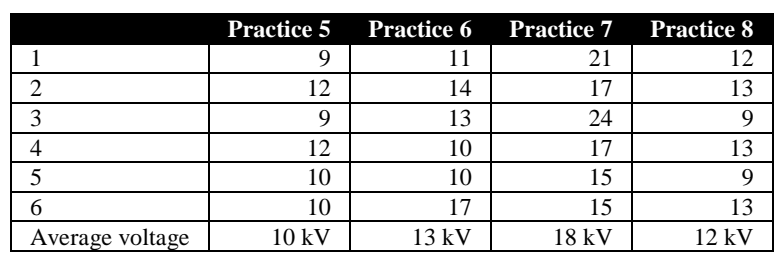

Table 8 Dielectric strength results Source: Own Elaboration

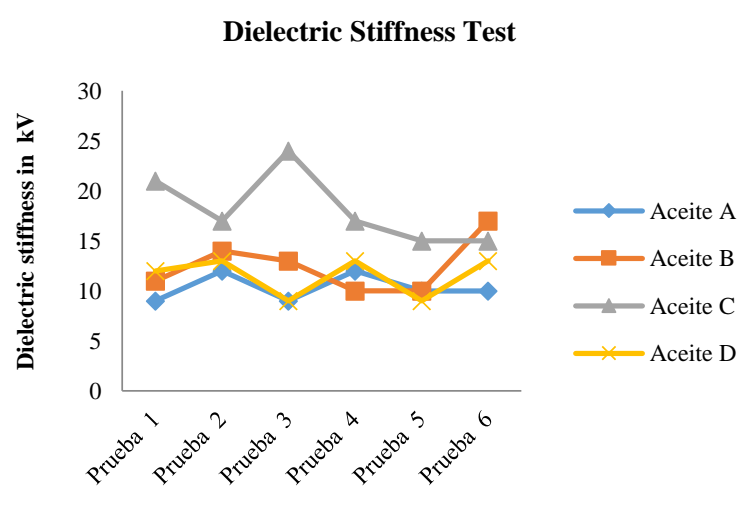

Graph 5 Dielectric strength

Source: Own Elaboration

Graph 5 shows the variation of the dielectric strength of practices $5,6,7$ and 8 considered oil A, oil B, oil C and oil D respectively of which oil $\mathrm{C}$ test can be considered of adequate quality due to its breakdown voltage.

ESCAMILLA-RODRÍGUEZ, Frumencio, LAGUNA-CAMACHO, Juan Rodrigo, RÍOS-HERNÁNDEZ, Sara Anahí and JIMÉNEZ-CRISTÓBAL, Juan Daniel. Rupture voltage in mineral oil using the megger OTS 60pb equipment to determine its quality and use in transformers. Journal of Experimental Systems. 2021 
Finally, a practice 9 was performed on another degraded mineral oil to observe its behavior with or without heat supply. This oil did not pass the UNE 21 test (5 minutes) under normal conditions $\left(15^{\circ} \mathrm{C}\right)$ and it was decided to supply it with heat, performing the practice again. This was done by increasing its temperature by 5 degrees, therefore, the following temperature readings were considered, $25^{\circ} \mathrm{C}, 30^{\circ} \mathrm{C}, 35^{\circ} \mathrm{C}$ and $40^{\circ} \mathrm{C}$. As the oil cooled very quickly, the first reading was $40^{\circ} \mathrm{C}$ and subsequently $35^{\circ} \mathrm{C}, 30^{\circ} \mathrm{C}$ and $25^{\circ} \mathrm{C}$, giving results that we can observe in the following table, to a certain extent expected, because the amount of humidity was decreased.

\begin{tabular}{|c|c|c|c|c|c|}
\hline & $\begin{array}{c}\text { Oil } \\
15^{\circ} \mathrm{C}\end{array}$ & $\begin{array}{c}\text { Oil } \\
25^{\circ} \mathrm{C}\end{array}$ & $\begin{array}{c}\text { Oil } \\
30^{\circ} \mathrm{C}\end{array}$ & $\begin{array}{c}\text { Oil } \\
35^{\circ} \mathrm{C}\end{array}$ & $\begin{array}{c}\text { Oil } \\
40^{\circ} \mathrm{C}\end{array}$ \\
\hline 1 & 10 & 42 & 54 & 39 & 41 \\
\hline 2 & 10 & 50 & 52 & 60 & 48 \\
\hline 3 & 9 & 35 & 50 & 50 & 40 \\
\hline 1 & 10 & 42 & 54 & 39 & 41 \\
\hline $\begin{array}{l}\text { Average } \\
\text { voltage }\end{array}$ & $10 \mathrm{kV}$ & $42 \mathrm{kV}$ & $52 \mathrm{kV}$ & $50 \mathrm{kV}$ & $43 \mathrm{kV}$ \\
\hline
\end{tabular}

Table 9 Results of practice 9 of mineral oil at different temperatures

Source: Own Elaboration

\section{Annexes}

\begin{tabular}{|c|l|l|l|}
\hline $\begin{array}{c}\text { Standard } \\
\text { test }\end{array}$ & EN60156 AS & CEI 10-1 & ASTM \\
& 1767 BS 5730 & TOCT 6581 & D1816 \\
& IEC156 IP & VDE 0370 & \\
& $\begin{array}{l}\text { 295 NFC 27 } \\
\text { SABS 555 } \\
\text { SATS 286 }\end{array}$ & AS1767 & \\
& UNE 21 & & \\
$\begin{array}{c}\text { Electrode } \\
\text { shape } \\
\text { Electrode } \\
\text { spacing }\end{array}$ & $-2.5 \mathrm{~mm}$ & & \\
\hline
\end{tabular}

Annex 1 Test specification and different types of electrodes

\begin{tabular}{|c|c|}
\hline \multicolumn{2}{|r|}{ onditions } \\
\hline Procedure A & Procedure A \\
\hline \multicolumn{2}{|c|}{$\begin{array}{l}\text { Tests should be repeated if the range of recorded breakdown voltages } \\
\text { is more than } 92 \% \text { of the mean. If the range of } 10 \text { breakdown voltages } \\
\text { is more than } 151 \% \text { the cause should be investigated. }\end{array}$} \\
\hline \multicolumn{2}{|l|}{ ASTM 1816} \\
\hline \multicolumn{2}{|c|}{$\begin{array}{l}\text { If the rupture does not occur at } 2 \mathrm{~mm} \text {, reduce the distance to } 1 \mathrm{~mm} \text {. } \\
\text { distance to } 1 \mathrm{~mm} \text {. Tests must be repeated if the range of breakdown } \\
\text { voltages } \\
\text { recorded is more than } 120 \% \text { of average } \\
\text { at } 1 \mathrm{~mm} \text { electrode spacing } \\
\text { and } 92 \% \text { of the average with } 2 \mathrm{~mm} \text { electrode spacing. } \\
\text { electrode spacing of } 2 \mathrm{~mm} \text {. }\end{array}$} \\
\hline \multicolumn{2}{|l|}{ IEC 60156} \\
\hline \multicolumn{2}{|c|}{$\begin{array}{l}\text { Expected range of the standard deviation to mean ratio as a function of } \\
\text { the mean is provided as a graph. } \\
\text { standard deviation to mean as a function of the mean is provided as a } \\
\text { graph. }\end{array}$} \\
\hline
\end{tabular}

Annex 2 Validation of the test in the different standards

\begin{tabular}{|l|l|l|l|}
\multicolumn{1}{c}{ Oil in service } & \multicolumn{3}{c|}{ Dielectric breakdown voltage } \\
\hline Equipment voltage & Well & Acceptable & Poor \\
\hline$\geq 72.5 \mathrm{kV}$ & $>40 \mathrm{kV}$ & $30-40 \mathrm{kV}$ & $>30 \mathrm{kV}$ \\
\hline$\geq 72.5 \mathrm{kV} \geq 170 \mathrm{kV}$ & $>50 \mathrm{kV}$ & $40-50 \mathrm{kV}$ & $>30 \mathrm{kV}$ \\
\hline$>270 \mathrm{kV}$ & $>60 \mathrm{kV}$ & $50-60 \mathrm{kV}$ & $>50 \mathrm{kV}$ \\
\hline
\end{tabular}

Annex 3 Breakdown voltage for oil in service IEC 60156

\begin{tabular}{|l|l|l|}
\hline \multicolumn{3}{|c|}{ ASTM D 877 Method } \\
\hline Acceptable & Dudoso & Unacceptable \\
\hline$\geq 30 \mathrm{kV}$ & $<32$ a $28 \quad \geq 25 \mathrm{kV}$ & $<25 \mathrm{kV}$ \\
\hline
\end{tabular}

Annex 4 Voltage range per ASTM D 877 standard

\section{Acknowledgements}

I would like to thank the School of Mechanical and Electrical Engineering, Poza Rica - Tuxpan area of the Universidad Veracruzana, for the facilities provided for the preparation of this article.

\section{Conclusions}

After analyzing the results of the mineral oil breaking strain, we can conclude the following: The practices carried out under the UNE 21 standard, are within the parameters of the standard. No result exceeds $10 \%$ of the mean value, therefore the result is valid. According to the parameters of the standard, the oil is in good condition for use. When applying BS 148, which gives the pass/fail option in practices 3 and 4 , where oil in service was used, it was found that the two samples comply with the standard, since the screen of the equipment shows the result when applying this standard (pass/fail). For practice 5 , contaminated oil was used under BS 148 , the result fails, as well as practices 6,7 and 8.

For practice 9, the oil used in practices 5, 6,7 and 8 was used again and when heat was supplied to it, the breaking strain of the oil improved considerably. According to the results of the practices and the confrontation of results with the parameters of the standards, the OTS60PB equipment operates correctly and it was concluded that all results of the operation of the equipment are reliable, that the instructions for handling the oil samples must be followed, since any contamination, no matter how small, can negatively affect the test results, thus generating an erroneous diagnosis of the oil conditions. 


\section{References}

CFE. (2003). Manual de procedimientos de prueba de campo para equipo de subestaciones de distribución. México, D.F.: CFE SDD.

Jorge Luis Ceballos Sánchez, Ernesto García Maldonado (2013). "Análisis Técnico del líquido contenido como Refrigerante y aislante en Transformadores". Tesis (Ingeniero Electricista). Instituto Politécnico Nacional.

Megger Limited Archcliffe Road Dover. (2003). La guía de Megger sobre las pruebas de ruptura dieléctrica de aceites de aislamiento. España.

Norma ASTM D181 (por sus siglas in ingles American Society for Testing and Materials)

Norma IEC 60156 (por sus siglas en ingles International Electrotechnical Commission)

Porragas Beltrán, L. H. (2009). Manual de Prácticas del Laboratorio de Máquinas Eléctricas. Veracruz, Veracruz, México.

TRAFO ELETTRO SRL. (2015). TRAFO ELETTRO.

http://www.trafoelettro.com/esp/aceite.html

Víctor Martínez García (1985). "Fabricación y usos de los Aceites Lubricantes". Tesis (Ingeniero Químico Industrial) Instituto Politécnico Nacional. https://es.scribd.com/document/342706827/Ace ites-Minerales-Aislantes-Para-

Transformadores-y-Aparamenta-de-Conexión 